\title{
HUBUNGAN ASUPAN ENERGI, SERAT, DAN PENGELUARAN ENERGI DENGAN RASIO LINGKAR PINGGANG-PANGGUL (RLPP)
}

\author{
Dwi Hartanti ${ }^{1}$ dan Tatik Mulyati ${ }^{1}$ \\ ${ }^{1}$ Program Studi Gizi, Fakultas Psikologi dan Kesehatan, Universitas Islam Negeri Walisongo, \\ Semarang \\ 2Departemen Ilmu Gizi, Fakultas Kedokteran, Universitas Diponegoro, Semarang \\ dwihartanti_gizi@yahoo.com
}

\begin{abstract}
The enbancement of WHR value which is one of abdominal obesity predictor is usually correlated with the rise of chronic disease risks because its relations with the metabolic syndrome. Dietary intake and energy expenditure factors may have the important role of balance energy that can increase WHR value. The aim of this study is to analyze correlation of energy expenditure, energy and fiber intake with waist hip ratio (WHR) of officers. This cross-sectional study was taken place at PT. Pertamina (Persero) Semarang with consecutive counted 55 sample. Energy and fiber intake was estimated by dietary food record $2 \times 24$ hour dan Semi-Quantitative Food Frequency Quesionaire. While energy expenditure was counted by using form diary activity. Statistic correlation was calculated by Statistic Package for the Social Science (SPSS) for window. About 70,9\% of total subject has abdominal obesity. The prevalence of abdominal obesity is higher in women (81,5\%) than men (60,7\%). The mean of energy intake is $2402.2 \pm 319.68 \mathrm{Kcal}$. Obese subject has 7,2\% higher energy intake than normal subject. About 40\% subject has light energy expenditure category and 45,5\% subject is belong to moderate energy expenditure category. About 96,4\% subject has fiber intake less than 25 gram per day. The result of this study shows that energy intake has association with $\operatorname{WHR}(r=0.455 ; p=0.000)$. Fiber intake is inversely associated with $\mathrm{WHR}(r=-0.382 ; p=0.004)$. Energy expenditure also bas negative association with $\mathrm{WHR}(r=-0.268 ; p=0.048)$. There are significantly correlation of energy expenditure, energy and fiber intake with WHR.
\end{abstract}

Keyword : abdominal obesity, energy intake, energy expenditure, fiber, waist-hip ratio

\section{PENDAHULUAN}

Pembangunan nasional yang dilaksanakan di Indonesia dalam semua aspek kehidupan telah meningkatkan taraf hidup dan kemakmuran masyarakatnya. Dengan adanya peningkatan kemakmuran dan ditambah adanya modernisasi menyebabkan terjadinya perubahan pada gaya hidup dan konsumsi pangan masyarakat khususnya di daerah perkotaan (Satoto et al. 1998). Pola makan tradisonal yang banyak mengandung karbohidrat dan serat 
kini cenderung bergeser menjadi pola makan modern dengan kandungan protein dan lemak yang tinggi tetapi miskin serat (Muchtadi Deddy 2001). Data Susenas 2003 menunjukan sebesar 61,29\% pengeluaran penduduk Jawa Tengah digunakan untuk kebutuhan pangan, sedangkan sisanya sebesar 38,71\% digunakan untuk kebutuhan non pangan ( BPS 2006 ).

Gaya hidup modern juga berdampak pada berkurangnya pengeluaran energi melalui aktivitas fisik pada masyarakat perkotaan (Muchtadi Deddy 2001). Hasil SKRT tahun 2004 menunjukkan lebih dari $84 \%$ dari kelompok umur 15 tahun ke atas termasuk kurang melakukan aktivitas fisik, sebesar 9,1\% bahkan tidak aktif, dan hanya $6 \%$ yang melakukan aktivitas fisik secara aktif (Bappenas 2006).

WHO tahun 2002 menyatakan bahwa diet tinggi energi serta pola hidup kurang gerak (sedentary lifestyle) adalah dua karakteristik yang sangat berkaitan dengan peningkatan prevalensi obesitas di seluruh dunia. Obesitas telah mengakibatkan lebih dari 2,5 juta kematian per tahun. Lokasi timbunan lemak pada tubuh merupakan salah satu faktor resiko yang berhubungan dengan terjadinya gangguan metabolik selain dari jumlah lemak yang tertimbun (Hamam Hadi 2005). Obesitas abdominal yang memiliki akumulasi lemak di bagian perut merupakan tipe obesitas yang paling sering dihubungkan dengan peningkatan resiko penyakit kronik karena keterkaitannya dengan sindroma metabolic (Laquatra I 2004). Obesitas abdominal lebih berbahaya dibandingkan dengan total timbunan lemak pada seluruh tubuh (Sienkiewicz and Whitney 2006).

Menurut Survei Nasional yang dilakukan pada tahun 1996/1997 di seluruh Ibukota Propinsi di Indonesia menunjukkan prevalensi obesitas pada penduduk dewasa ( $\geq 18$ tahun) laki-laki adalah 6,8\% dan perempuan 13,5\% (Soegondo Sidartawan 2005). Sebuah penelitian pada orang dewasa $>18$ tahun di Padang mendapatkan prevalensi obesitas abdominal yang diukur menggunakan rasio lingkar pinggang-panggul (RLPP) yang dikaitkan dengan resiko terhadap penyakit degeneratif sebesar 50\%. Proporsi perempuan yang beresiko lebih besar (59\%) daripada laki-laki (13,6\%) (Sudarmani Djoko 1997).

Salah satu indikator untuk menilai obesitas abdominal adalah dengan pengukuran rasio lingkar pinggang-panggul (RLPP) (Worobey J 2006). Pengukuran antropometri tersebut dapat menggambarkan distribusi lemak dalam tubuh khususnya timbunan lemak di rongga perut. RLPP diperoleh dengan membandingkan lingkar pinggang dengan lingkar panggul (Fink et al 2006) Batas ukuran RLPP untuk terjadinya resiko obesitas abdominal adalah 0,90 pada laki-laki dan 0,80 pada perempuan (Gibson 2005).

Kelebihan asupan energi dan kurangnya aktivitas fisik berpengaruh pada peningkatan ukuran RLPP (Trichopoulou et al 2001). Hal ini 
berhubungan dengan ketidakseimbangan energi yang memicu pertambahan akumulasi lemak dalam tubuh (Hamam Hadi 2005). Di sisi lain, asupan serat memiliki hubungan negatif dengan RLPP (Ludwig et al 1999). Serat mampu menurunkan sekresi insulin yang merupakan hormon anti-lipolitik yang dapat membuat lemak banyak tertimbun dalam tubuh khususnya pada bagian abdomen (Fogoros 2007)

Faktor lingkungan terutama lingkungan kerja kantor di perkotaan diketahui sebagai salah satu faktor timbulnya obesitas (Mummery et al 2005). Peningkatan pendapatan dan kesibukan kerja yang tinggi membuat para pegawai kantor cenderung sering mengkonsumsi makanan cepat saji yang berkalori tinggi dan rendah serat. Selain itu aktifitas kerja di kantor yang hanya duduk dalam bekerja mempersempit peluang para pekerja kantor untuk melakukan gerak fisik yang optimal. Adanya ketidakseimbangan asupan dan pengeluaran energi ini menyebabkan peningkatan timbunan lemak dalam tubuh (Muchtadi 2001).

Berdasarkan permasalahan diatas, perlu diteliti tentang hubungan asupan energi, serat dan pengeluaran energi dengan rasio lingkar pinggangpanggul (RLPP) di kalangan pegawai yang tinggal di daerah perkotaan.

\section{METODE}

Penelitian ini merupakan penelitian penjelasan (explanatory research), dengan rancangan cross-sectional (belah lintang). Penelitian dilakukan di PT. Pertamina (Persero) Semarang pada bulan Mei 2012. Penelitian ini termasuk dalam penelitian gizi masyarakat.

Populasi penelitian ini adalah Karyawan PT. Pertamina (Persero) Semarang dengan jumlah subyek sebanyak 55 orang. Cara pengambilan subyek dilakukan dengan metode consecutive sampling dengan kriteria inklusi yaitu tidak sedang melakukan diet khusus, tidak hamil dan belum menopause pada wanita, tidak memiliki kebiasaan merokok, tidak memiliki kebiasaan minum alkohol. Variabel yang diteliti meliputi asupan energi, asupan serat dan pengeluaran energi sebagai variabel bebas serta rasio lingkar pinggang-panggul (RLPP) sebagai variabel terikat.

Asupan energi dan asupan serat adalah jumlah asupan energi dan asupan serat dari makanan utama dan selingan yang dikonsumsi per hari oleh subyek. Data diperoleh dengan menggunakan form dietary food record 2 x 24 jam dan semi-quantitative food frequency quesionaire. Asupan energi dan serat dihitung rerata per hari kemudian dikonversikan ke dalam satuan kcal untuk asupan energi dan gram untuk asupan serat dengan menggunakan program nutrisoft.

Pengeluaran energi adalah banyaknya energi yang dikeluarkan untuk melakukan aktivitas secara teratur dalam waktu 1x24 jam. Pengeluaran energi 
dihitung berdasarkan jenis dan lama aktivitas yang dilakukan (dalam jam). Pada perhitungan pengeluaran energi tersebut sudah memperhitungkan basal metabolisme, kelipatan metabolik aktivitas dan durasi aktivitas (Williams 1995). Data tentang pengeluaran energi diperoleh dari form diary activity.

Rasio lingkar pinggang-panggul (RLPP) adalah indikator untuk menentukan obesitas abdominal yang diperoleh dengan menghitung perbandingan antara lingkar pinggang dengan lingkar panggul. Lingkar pinggang diperoleh dari panjang lingkar perut yang menghubungkan dua SIAS (Supra Iliaca Anterior Superior) melewati pusar / umbilikus. Lingkar panggul diperoleh dengan cara mengukur lingkar maksimal dari pantat. Dikarenakan faktor etika pengukuran lingkar pinggang dan lingkar panggul pada subyek yang masih mengenakan pakaian maka dilakukan koreksi pengukuran sebesar $3 \mathrm{~cm}$. Batas ukuran RLPP untuk kategori obesitas abdominal adalah 0,9 untuk laki-laki dan 0,8 untuk perempuan (Gibson 2005).

Analisis data menggunakan program Statistic Package for the Social Science (SPSS) for windows. Analisis univariat dilakukan untuk mendeskripsikan data karakteristik subyek, ukuran RLPP, asupan energi, asupan serat dan pengeluaran energi. Analisis bivariat untuk menghubungkan masing-masing variabel bebas dengan variabel terikat menggunakan Uji Rank Spearman karena data tidak berdistribusi normal.

\section{HASIL DAN PEMBAHASAN}

Jumlah subyek pada penelitian ini adalah 55 orang, terdiri dari 28 orang (50,9\%) laki-laki dan 27 orang $(49,1 \%)$ perempuan. Rentang usia subyek berkisar antara 25 - 53 tahun. Pendidikan terakhir sebagian besar subyek adalah perguruan tinggi yaitu sebanyak 49 orang $(89,1 \%)$.

Tabel 1. Distribusi Sampel menurut Jenis Kelamin dan Pendidikan Terakhir

\begin{tabular}{cccc}
\hline & Kategori & Frekuensi & Persen \\
\hline Jenis Kelamin & Laki-laki & 28 & 50.9 \\
& Perempuan & 27 & 49.1 \\
\hline \multirow{2}{*}{ Pendidikan } & SMA & 6 & 10.9 \\
& Perguruan Tinggi & 49 & 89.1 \\
\hline
\end{tabular}


Tabel 2. Rerata, Nilai Minimum, Nilai Maksimum dan Standard

Deviasi Usia Sampel

\begin{tabular}{cccccc}
\hline & $\mathrm{n}$ & Minimum & Maksimum & Mean & $\begin{array}{c}\text { Std. } \\
\text { Deviasi }\end{array}$ \\
\hline Usia & 55 & 25 & 53 & 39.33 & 9.24 \\
\hline Kategori & & & & & \\
$-\quad$ Laki-laki & 28 & 26 & 53 & 40.61 & 8.53 \\
$-\quad$ Perempuan & 27 & 25 & 49 & 38 & 9.90 \\
\hline
\end{tabular}

Pada penelitian ini didapatkan prevalensi obesitas abdominal sebesar $70,9 \%$. Tingginya prevalensi obesitas abdominal mungkin berkaitan dengan faktor usia dimana rerata usia subyek adalah $39.33 \pm 9.24$ tahun. Berat badan maksimum seseorang umumnya terjadi pada usia sekitar 40 tahu (Seogondo 2005). Pertambahan usia berhubungan dengan makin meningkatnya akumulasi lemak tubuh. Subyek yang tergolong usia dewasa akhir ( $\geq 45$ tahun) yaitu sebanyak $41.8 \%$. Masa dewasa akhir cenderung memiliki persen lemak tubuh yang lebih tinggi di bandingkan dengan pada masa remaja atau dewasa awal (Espeland et al 1997). Pada umumnya laki-laki dan perempuan mengalami peningkatan berat badan yang paling signifikan pada usia 25-34 tahun dan akan terus meningkat hingga usia 55 tahun namun dengan tahapan peningkatan yang lebih rendah (Worobey J 2006). Hal inilah yang berpengaruh terhadap peningkatan ukuran RLPP.

Prevalensi obesitas abdominal lebih tinggi pada perempuan (81,5\%) dibandingkan dengan laki-laki (60,7\%). Hal ini mungkin disebabkan karena usia sebagian besar subyek perempuan mendekati usia menopause. Usia subyek perempuan yang berada di atas 45 tahun yaitu sebesar $40.7 \%$, dimana usia ini merupakan usia pra-menopause. Usia pra menopause adalah 5 tahun sebelum masa menopause dimana rerata usia wanita menopause adalah 51 tahun. Penelitian oleh Espeland MA et al, menyatakan bahwa ukuran RLPP berhubungan secara signifikan dengan usia pra-menopause. Wanita pada usia antara 45 hingga 54 tahun memiliki ukuran rasio lingkar pinggang-panggul lebih tinggi (Espeland et al 1997). Perempuan pada masa menopause umumnya cenderung memiliki distribusi lemak pada daerah perut (tipe android) atau disebut obesitas abdominal (Katch FI and Mc Ardle 1993). Pada usia ini, aktivitas hormon esterogen untuk menstimulasi liposis pada bagian abdomen menjadi berkurang, sehingga timbunan lemak lebih banyak terdistribusi pada daerah abdomen dan mengakibatkan peningkatan ukuran RLPP (Laquatra 2006). 


\section{Asupan Energi dan Serat}

Asupan energi berkisar antara 1590 Kalori - 2936 Kalori. Asupan energi pada subyek laki-laki lebih tinggi dari subyek perempuan. Sebanyak 36 subyek (65,5\%) memiliki asupan energi melebihi Angka Kecukupan Gizi (AKG), 19 subyek (34,5\%) memiliki asupan energi kurang dari AKG (Supariasa 2002). Asupan serat seluruh sampel berkisar antara 6.29 gram sampai 26.79 gram. Sebanyak 53 subyek (96,4\%) memiliki asupan serat lebih rendah dari anjuran per hari yaitu 25gram/hari (Nainggolan 2005).

Tabel 3. Distribusi Sampel menurut Asupan Energi dan Serat

\begin{tabular}{cccc}
\hline & Kategori & Frekuensi & Persen \\
\hline Asupan energy & Lebih AKG & 36 & 65,5 \\
& Kurang AKG & 19 & 34,5 \\
\hline \multirow{2}{*}{ Asupan serat } & Kategori & Frekuensi & Persen \\
& & & \\
\hline & Normal & 2 & 3,6 \\
& Kurang & 53 & 96,4 \\
\hline
\end{tabular}

Asupan energi merupakan jumlah kalori yang dikonsumsi dalam satu hari. Asupan energi melalui makanan harus sesuai dengan kebutuhan masingmasing individu (Nursanyoto 1992). Kelebihan energi terjadi bila asupan energi melalui makanan melebihi energi yang dikeluarkan melalui aktivitas fisik, sehingga kelebihan energi ini akan disimpan menjadi lemak tubuh (Almatsier 2002) Sebanyak 65,5\% subyek memiliki asupan energi melebihi Angka Kecukupan Gizi (AKG). Rerata asupan energi seluruh subyek adalah $2402.2 \pm$ 319.68 Kcal. Tingginya asupan energi pada sebagian besar subyek dikarenakan banyak mengkonsumsi makanan siap saji yang dibeli di warung sekitar kantor untuk makan siang yang merupakan makanan yang tinggi kalori.

Hasil penelitian menunjukkan bahwa sebanyak 44 orang subyek $(80 \%)$ mengalami balance energi positif. Hal ini ditandai dengan lebih besarnya asupan energi dibanding dengan pengeluaran energi. Untuk proses faali tubuh dan melakukan kegiatan sehari-hari maka kebutuhan energi untuk laki-laki dewasa berkisar antara $1.900-2.700 \mathrm{Kkal} /$ hari, sedangkan pada wanita antara 1.700 - 2.100 Kkal./hari (Nursanyoto 1992). Rerata asupan energi pada subyek laki-laki lebih tinggi dibandingkan dengan subyek perempuan. Namun perbedaannya tidak terlalu signifikan.

Asupan serat sebagian besar subyek berada di bawah anjuran yang direkomendasikan yaitu sebesar 25 gram per hari. Sebanyak 96,4\% sampel memiliki asupan serat kurang. Dari hasil record dan FFQ diketahui bahwa sampel kurang mengkonsumsi sayur dan buah sehingga mengakibatkan asupan 
serat menjadi rendah. Selain itu kebanyakan sampel sering makan di luar rumah atau mengkonsumsi makanan siap saji tinggi energi yang di beli di warung. Makanan tinggi energi pada umumnya memiliki kandungan serat yang rendah (Nainggolan 2005).

\section{Pengeluaran Energi dan Rasio RLPP}

Pengeluaran energi sampel berkisar antara 1614.59 kalori - 2686.75 kalori. Sebanyak 22 orang subyek (40\%) memiliki pengeluaran energi kategori ringan dan 25 orang $(45,5 \%)$ termasuk pengeluaran energi kategori sedang. Kategori pengeluaran energi adalah ringan ( $\leq 2000$ kalori), sedang (2001-2400 kalori), berat (2401-2600 kalori) dan sangat berat (2601-3000 kalori) (Kartasapoetra dan Marsetyo 2003).

Tabel 4. Distribusi Sampel menurut Pengeluaran Energi dan Rasio Lingkar Pinggang-panggul (RLPP)

\begin{tabular}{cccc}
\hline & Kategori & Frekuensi & Persen \\
\hline Aktivitas Fisik & Ringan & 22 & 40 \\
& Sedang & 25 & 45.5 \\
& Berat & 5 & 9.1 \\
& Sangat berat & 3 & 5.5 \\
\hline RLPP & Normal & 11 & 39.3 \\
Laki-laki & Obesitas & 17 & 60.7 \\
\hline RLPP & Normal & 5 & 18.5 \\
Perempuan & Obesitas & 22 & 81.5 \\
\hline
\end{tabular}

Sebanyak 22 orang subyek (40\%) memiliki pengeluaran energi kategori ringan dan 25 orang $(45,5 \%)$ termasuk pengeluaran energi kategori sedang. Hanya sebagian kecil subyek yang memiliki pengeluaran energi kategori berat $(9,1 \%)$ dan sangat berat $(5,5 \%)$. Aktivitas sebagai pegawai kantor merupakan kategori aktivitas fisik ringan sampai sedang. Hal ini dikarenakan aktivitas kerja di kantor yang pasif dan hanya duduk dalam bekerja mempersempit peluang para pekerja kantor untuk melakukan gerak fisik yang optimal (Muchtadi 2001).

Berdasarkan data yang dikumpulkan dalam penelitian ini, aktivitas subyek lebih banyak untuk melakukan pekerjaan di kantor. Karyawan PT. Pertamina (Persero) Semarang pada umumnya memiliki jam kerja selama 6 8 jam perhari. Mereka bekerja dari pukul 07.00 hingga pukul 16.00 dengan istirahat siang selama $1 \mathrm{jam}$. Sebagian besar karyawan bekerja di kantor dengan posisi duduk dalam bekerja. Semakin lama seseorang duduk dalam bekerja, semakin seseorang itu memiliki kecenderungan mengalami kelebihan berat 
badan. Pekerjaan kantor mungkin merupakan faktor penting dalam epidemik obesitas. Jumlah total bekerja sambil duduk sehari-hari yang relatif tinggi dihubungkan dengan 68\% peningkatan risiko terjadinya kelebihan berat badan. Sebuah studi yang dilakukan di Australia oleh Mummery WK, Brown, W, Schofield, G., Eakin, E, dan Steele, $R$ menemukan adanya hubungan antara jumlah lama duduk dengan tingkat kelebihan berat badan (Mummery 2005).

Pengeluaran energi melalui aktivitas yang biasa dilakukan sebagian besar subyek di rumah juga merupakan aktivitas yang ringan seperti duduk santai, membaca, menemani anak belajar, dan menonton televisi. Pada penelitian ini juga ditemukan subyek yang termasuk dalam pengeluaran energi kategori berat dan sangat berat (>2400 kalori). Hal ini dikarenakan aktivitas subyek selain melakukan pekerjaan kantor juga melakukan survei lapangan yang memerlukan pengeluaran energi yang lebih tinggi.

Nilai RLPP seluruh sampel berkisar antara 0.74 - 1.00. Ukuran RLPP untuk terjadinya resiko obesitas abdominal adalah 0,90 pada laki-laki dan 0,80 pada perempuan (Gibson 2005). Sebanyak 70,9\% sampel termasuk dalam kategori obesitas abdominal. Prevalensi obesitas abdominal pada laki-laki adalah 60,7\% sedangkan pada perempuan adalah 81,5\%.

Rerata RLPP pada sampel laki-laki adalah 0.91 dan rerata RLPP pada sampel perempuan adalah 0.85. Ukuran RLPP untuk terjadinya resiko obesitas abdominal adalah 0,90 pada laki-laki dan 0,80 pada perempuan (Gibson 2005). Pengukuran rasio lingkar pinggang-panggul merupakan metode yang paling sederhana untuk mendeskribsikan lemak subkutan dan jaringan lemak pada intra abdominal. Lingkar pinggang akan menggambarkan lemak tubuh dan tidak termasuk sebagian besar berat tulang (kecuali tulang belakang) atau massa otot yang besar, yang mungkin akan bervariasi dan mempengaruhi hasil pengukuran. Ukuran ini berkorelasi paling dekat dengan rasio lingkar pinggang-panggul (RLPP) baik pada laki-laki dan perempuan serta dapat menentukan luas obesitas abdominal, yang tampaknya sudah mendekati deposisi lemak abdominal yang visceral (Soegondo 2005).

Ukuran RLPP menggambarkan peningkatan relatif dari ukuran lingkar pinggang dan penurunan relatif dari ukuran lingkar panggul. RLPP membedakan antara lemak lower trunk (panggul dan pantat) dengan lemak upper trunk (pinggang dan perut) (Seidell et al 2001). Rasio lingkar pinggang-panggul diperoleh dengan menghitung perbandingan antara lingkar pinggang dengan lingkar panggul (Gibson 2005). Obesitas abdominal memiliki hubungan dengan terjadinya sindroma metabolik. Hal ini dikarenakan lemak pada daerah perut sangat sensitif terhadap stimulasi lipolitik jika dibandingkan dengan lemak subkutan. Mobilisasi asam lemak bebas akan lebih cepat dari daerah abdomen. Lipolisis pada daerah ini membuat pelepasan asam lemak bebas ke sirkulasi 
akan meningkat. Keadaan inilah yang mengakibatkan terjadinya hiperinsulinemia, hiperlipidemia dan hipertensi (Laquatra 2006).

\section{Hubungan Asupan Energi dengan RLPP}

Diperoleh hubungan antara asupan energi dengan RLPP ( $r=0.455$; $\mathrm{p}=0.000)$. Hubungan asupan energi dengan RLPP menunjukkan arah hubungan yang positif, artinya semakin besar asupan energi maka nilai RLPP semakin meningkat. Orang yang mengalami obesitas cenderung memiliki asupan energi melebihi energi yang dikeluarkan. Subyek yang termasuk kategori obesitas memiliki rerata konsumsi energi 7,2\% lebih banyak jika dibandingkan dengan subyek yang RLPPnya tergolong normal. Sebanyak 89,7\% subyek yang termasuk dalam kategori obesitas memiliki asupan energi melebihi keluaran energi melalui aktivitas fisik. Hal ini mengakibatkan terjadinya balance energi positif yang pada akhirnya dapat menyebabkan obesitas (Nursanyoto 1992).

Menurut Trichopoulu asupan energi yang tinggi dan kurangnya aktivitas fisik berhubungan dengan peningkatan ukuran rasio lingkar pinggang panggul (Trichopoulou et al 2001). Konsumsi energi dalam jumlah yang berlebihan secara terus-menerus akan meningkatkan timbunan lemak dalam tubuh. Hal ini sesuai dengan hukum kekekalan energi yang menyatakan bahwa energi tidak akan bisa lenyap tetapi berubah dari satu bentuk ke bentuk lainnya (Nursanyoto 1992). Perubahan lemak tubuh sama dengan perbedaan antara asupan dan pengeluaran energi.

Lemak tubuh atau biasa disebut dengan jaringan adiposa merupakan suatu jaringan ikat yang dibangun oleh lemak yang berfungsi sebagai cadangan energi dalam tubuh. Jumlah simpanan lemak ini tergantung dari asupan energi. Asupan energi yang berlebihan akan menyebabkan cadangan lemak meningkat, demikian pula sebaliknya. Wanita umumnya mempunyai lemak tubuh lebih banyak dibandingkan dengan laki-laki (Nursanyoto 1992). Jumlah lemak tubuh tergantung dari individu masing-masing. Laki-laki normal biasanya memiliki 12 - 20\% lemak dalam tubuh, sedangkan perempuan memiliki jumlah lemak tubuh lebih banyak yaitu 20 - 30\% (Whitney and Rolfes 2002).

Dalam tubuh, lemak akan terdistribusi pada bagian-bagian tertentu. Distribusi lemak tubuh ini dipengaruhi oleh berbagai variable, salah satunya adalah aktivitas enzim dalam tubuh. Enzim lipoprotein lipase (LPL) merupakan enzim yang berpengaruh pada perbedaan distribusi lemak pada tubuh (Katch and Ardle 1993). Tingkat aktifitas LPL yang tinggi pada sel-sel lemak di daerah abdomen akan mengakibatkan timbunan lemak pada daerah tersebut akan meningkat. Hal inilah yang menyebabkan seseorang mengalami 
obesitas abdominal yang ditandai dengan peningkatan ukuran RLPP (Worobey 2006).

Metabolisme lemak di daerah abdomen yang distimulasi oleh beberapa hormon juga menyebabkan penimbunan lemak di daerah ini. Hormon katekolamin merupakan hormon yang menstimulasi lipolisis yang paling aktif di bagian visceral (intra abdominal). Selain itu terdapat pula hormon antilipolisis seperti insulin, prostaglandin dan adenosine yang cenderung menghambat pemecahan lemak. Hormon anti-lipolisis ini juga meningkatkan aktivitas LPL pada daerah abdomen (Arner et al 1997).

\section{Hubungan Pengeluaran Energi dengan RLPP}

Diperoleh hubungan antara pengeluaran energi dengan RLPP ( $\mathrm{r}=$ 0.268 ; $\mathrm{p}=0.048$ ). Hubungan pengeluaran energi dengan RLPP menunjukkan arah hubungan yang negatif, artinya semakin rendah pengeluaran energi maka nilai RLPP semakin meningkat. Pengeluaran energi melalui aktivitas fisik adalah setiap gerakan tubuh yang dilakukan otot-otot rangka yang menghasilkan pengeluaran sejumlah energi. Aktifitas fisik merupakan komponen dari pengeluaran energi (Whitney and Rolfes 2002). Asupan energi yang melebihi dari energi yang dikeluarkan untuk aktifitas fisik dapat mengakibatkan ketidakseimbangan energi dalam tubuh. Energi yang tidak terpakai dalam tubuh akan disimpan sebagai lemak dan terakumulasi dalam selsel lemak di jaringan adiposa (Sienkiewicz and Whitney 2006).

Peningkatan prevalensi obesitas berkorelasi dengan penurunan tingkat pengeluaran energi melalui aktivitas fisik. Pada studi cross-sectional oleh Troisi R, Heinhold J, Vokonas $\mathrm{P}$, Weiss $\mathrm{S}$ dinyatakan bahwa peningkatan pengeluaran energi berhubungan dengan penurunan nilai RLPP (Troisi et al 1991). Pengeluaran energi melalui aktivitas fisik mampu menurunkan lemak yang tertimbun pada bagian sentral dengan meningkatkan kebutuhan energi tubuh (Samaras and Campbell 1997).

Pengeluaran energi memiliki hubungan negatif dengan obesitas abdominal. Semakin tinggi aktivitas seseorang maka RLPP semakin berkurang (Sienkiewicz and Whitney 2006), dan semakin rendah pengeluaran energi maka akan terjadi peningkatan obesitas abdominal (Whitney and Rolfes 2002). Lemak pada bagian abdominal dan viseral memiliki aktivitas metabolik paling tinggi. Pada situasi dimana tubuh memerlukan energi, seperti saat melakukan aktivitas fisik, maka lemak yang tertimbun di bagian abdomen akan dimobilisasi lebih banyak dibandingkan dengan lemak di bagian tubuh lain (Arner et al 1997). Peningkatan pengeluaran energi melalui aktivitas fisik akan mengurangi jumlah lemak yang tertimbun di daerah perut (Fogoros 2007). Penelitian Pauline KB et al tahun 2003 mendapatkan hasil bahwa aktifitas fisik 
dapat mengurangi obesitas abdominal melalui penggunaan atau pembakaran lemak yang lebih banyak di daerah abdomen dibanding dengan lemak di bagian gluteal (Pauline 2003). Aktivitas fisik dapat menstimulasi aktivitas enzim LPL pada otot dan mengurangi aktivitas enzim tersebut pada lemak, sehingga lemak cenderung termobiliasi untuk pembentukan tenaga (Samaras and Campbell 1997).

\section{Hubungan Asupan Serat dengan RLPP}

Ada hubungan antara asupan serat dengan $\operatorname{RLPP}(\mathrm{r}=-0.382 ; \mathrm{p}=$ 0.004). Hubungan asupan serat dengan RLPP menunjukkan arah hubungan yang negatif, artinya semakin rendah asupan serat maka nilai RLPP semakin meningkat. Sebagian besar sampel memiliki asupan serat yang rendah yaitu $<25$ gram/hari. Nilai kecukupan asupan serat makanan yang dianjurkan untuk orang Indonesia adalah sebanyak adalah 25 gram per hari dengan mengutamakan serat larut air (Nainggolan 2005).

Pola makan masyarakat di kota-kota besar telah bergeser dari pola makan tradisional yang mengandung banyak karbohidrat, serat, dan sayuran ke pola makan modern yang komposisinya banyak mengandung protein, lemak, gula, dan garam tetapi miskin serat, sehingga mempunyai mutu gizi yang tidak seimbang (Uauy 2001) Hasil penelitian Puslitbang Gizi menunjukan rata-rata konsumsi serat penduduk Indonesia sebesar 10,5 gram per hari, sedangkan rata-rata konsumsi serat penduduk Jateng 12,8 gram per hari atau sekitar 1/3 dari kecukupan serat yang dianjurkan yaitu 25-35 gram per hari (Depkes RI 2001) Menurut sebuah penelitian oleh Jahari A.B dan Sumarno I diketahui bahwa tidak ada perbedaan konsumsi serat masyarakat di pedesaan dengan masyarakat di perkotaan. Konsumsi serat di desa 10,7 \pm 8,1 gram/hari sedangkan rerata konsumsi serat di perkotaan sebesar 9,9 $\pm 6,0$ gram/hari (Nainggolan 2005).

Asupan serat yang cukup tiap hari mampu mengontrol dan mempertahankan berat badan normal. Hal ini disebabkan serat mampu melapisi mukosa usus halus yang akan meningkatkan kekentalan volume makanan dan memperlambat penyerapan glukosa, sehingga peningkatan kadar serat di dalam diet dapat menurunkan penyerapan energi. Serat juga mampu memberikan perasaan kenyang lebih lama, sehingga keinginan untuk mengasup makanan lain (termasuk sumber energi) menjadi berkurang. Dengan berkurangnya asupan energi maka akan berpengaruh pada berkurangnya akumulasi lemak dalam tubuh yang pada akhirnya mengarah pada penurunan obesitas (Wirakusumah dan Emma 2001).

Serat larut air (soluble fiber) seperti pectin, gum serta beberapa hemiselulosa mempunyai kemampuan menahan air dan dapat membentuk cairan kental 
dalam saluran pencernaan. Dengan kemampuan ini serat larut dapat menunda pengosongan makanan dari lambung, menghambat pencampuran isi saluran cerna dengan enzim-enzim pencernaan, sehingga terjadi pengurangan penyerapan zat-zat makanan. Mekanisme inilah yang menyebabkan terjadinya penurunan penyerapan (absorbsi) asam amino dan asam lemak oleh serat larut air (Nainggolan 2005).

Makanan dengan kandungan serat kasar juga dapat menurunkan berat badan. Makanan akan tinggal dalam saluran pencernaan dalam waktu yang relatif singkat sehingga absorbsi zat makanan akan berkurang. Selain itu makanan yang mengandung serat relatif tinggi akan memberi rasa kenyang sehingga menurunkan konsumsi makanan. Makanan dengan kandungan serat kasar yang tinggi biasanya mengandung kalori rendah, kadar gula dan lemak rendah yang dapat membantu mengurangi terjadinya obesitas (Nainggolan 2005).

Hasil penelitian ini menunjukkan bahwa semakin rendah asupan serat maka nilai RLPP semakin tinggi. Hal ini sesuai dengan penelitian oleh Ludwig DS, et al tahun 1999 yang menyimpulkan bahwa konsumsi serat berpengaruh terhadap nilai RLPP. Serat dapat menurunkan obesitas abdominal yang diukur dengan menggunakan RLPP. Asupan serat dapat meningkatkan sensitivitas insulin. Sensitivitas insulin adalah kemampuan dari hormon insulin menurunkan kadar glukosa darah dengan menekan produksi glukosa hepatik dan menstimulasi pemanfaatan glukosa di dalam otot skeletal dan jaringan adiposa. Pada keadaan dimana sensitivitas insulin menurun maka hormon insulin tidak dapat menangkap glukosa untuk dapat masuk dan dimanfaatkan ke dalam sel, sehingga glukosa akan disimpan dalam tubuh sebagai timbunan lemak. Hal inilah yang menimbulkan peningkatan timbunan lemak yang cenderung berada di bagian abdominal. Hormon Insulin dapat membuat lemak banyak tertimbun dalam tubuh khususnya pada bagian yang berbahaya yaitu pada bagian visceral, di sekitar liver, jaringan di bagian jantung dan sel $\beta$ pancreas (Mummery et al 2005).

Serat berhubungan dengan penurunan akumulasi lemak dan berat badan melalui mekanisme hormon insulin. Asupan serat berpengaruh pada penurunan tingkat sirkulasi hormon insulin dan mencegah hiperinsulinemia. Peningkatan hormon insulin (hiperinsulinemia) dalam tubuh dapat berakibat pada kejadian obesitas terutama obesitas abdominal melalui peningkatan aktivitas LPL di bagian abdomen, penghambatan lipolisis (pemecahan lemak), mengurangi efek thermogenesis dan meningkatkan nafsu makan. Sehingga asupan serat yang dapat menurunkan sekresi hormon insulin mampu mengurangi akumulasi lemak pada perut (Mummery et al 2005). 


\section{KESIMPULAN}

Sebanyak 70,9\% subyek termasuk obesitas abdominal, dimana perempuan (81,5\%) lebih tinggi dibandingkan laki-laki (60,7\%). Ada hubungan antara asupan energi, serat dan pengeluaran energi dengan RLPP.

\section{DAFTAR PUSTAKA}

Almatsier S. 2002. Prinsip Dasar Ilmu Gizi. Jakarta: Gramedia Pustaka Utama. Arner P. 1997. Obesity and The Adipocyte - Regional adipocity in man. Journal of Endocrinology ;155:192-191

Badan Perencanaan Pembangunan Nasional. 2006. Rencana Aksi Nasional Pangan dan Gizi 2006-2010. Available from http:// www.bappenas.go.id/index.php

Badan Pusat Statistik. 2003. Pemerataan Pendapatan dan Pola Konsumsi Penduduk Jawa Tengah 2003. Semarang: Badan Pusat Statistik Propinsi Jawa Tengah

Departemen Kesehatan Republik Indonesia. 2001. Penelitian Pangan dan Gizi. Badan Penelitian dan Pengembangan: Bogor.

Espeland MA, Stefanick ML, Silverstein DK, Fineberg SE, Waclawiw MA, James MK, et al. 1997. Effect of Postmenopausal Hormone Therapy on Body Weight and Waist and Hip Girths 1 . The Journal of Clinical Endocrinology \& Metabolism [serial online];82(5):p.1549-1556

Fink H, Burgoon LA, Mikesky AE. 2006. Practical application sport nutrition. Sudbury, Massachusetts. Jones and Bartlett. p.322-321.

Fogoros R. 2007. Abdominal Obesity and Its Link to Metabolic Syndrome. Availlable from http://metabolicsyndrome.about.com

Gibson RS. 2005. Antropometric Assessment of Body Composition. Dalam: Principle and Nutritional Assessment second edition. USA: Oxfort University Press; hal 273-285.

Hamam Hadi. 2005. Beban Ganda Masalah Gizi dan Implikasinya terhadap Kebijakan Pembangunan Kesehatan Nasional. Dalam : Pidato Pengukuhan Jabatan Guru Besar pada Fakultas Kedokteran Universitas Gadjah Mada Yogyakarta: UGM.

Kartasapoetra G, Marsetyo H. 2003. Ilmu Gizi. Korelasi Gizi, Kesehatan dan Produktivitas Kerja. Jakarta : Rineka Cipta.

Katch FI, Mc Ardle. Obesity. 1993. In : Introduction to Nutrition, Exercise, and Health. $4^{\text {th }}$ ed. Philadelphia:Lea and Febiger;.p.263-260

Laquatra I. Nutrition for weight management. In : Mahan $1 \mathrm{k}$, Escott-Stump S. Krause's Food, Nutrition, \& Diet Therapy. Philadelphia: Saunders; 2004 
Ludwig DS, Pereira MA, Kroenke CH, Hilner JE, Van Horn L, Slattery ML, et al. Dietary Fiber, Weight Gain, and Cardiovascular Disease Risk Factors in Young Adults. JAMA [serial online] 1999;282:1546-1539

Muchtadi, Deddy. 2001. Pangan dan Gizi - Pencegahan Gizi Lebih dan Penyakit Kronis Melalui Perbaikan Pola Konsumsi Pangan. Penerbit : Sagung Seto, Institute Pertanian Bogor.hal.94-103

Mummery, WK., Brown, W., Schofield, G., Eakin, E., \& Steele, R. (2005). Relationships between occupational sitting time and overweight and obesity in Australian workers. Paper presented at the Australian Society for Behavioral Health and Medicine Conference, Melbourne, Australia.

Nainggolan O, Cornelis Adimunca. 2005. Diet Sehat Dengan Serat. Pusat Penelitian dan Pengembangan Pemberantasan Penyakit Badan Penelitian dan Pengembangan Kesehatan. Departemen Kesehatan RI. Cermin Dunia Kedokteran ; 147

Nursanyoto Hertog. 1992. Ilmu Gizi Zat Gizi Utama. Jakarta : Golden Terayon Press; hal.77-101

Pauline KB. 2003. Prospective study of the association of changes in dietary intake,physical activity, alcohol consumption, and smoking with 9-y gain in waist circumference among 16587 US men. Am J Clin Nutr;78:719-27

Samaras K, Campbell LV. 1997. Mini review-The Non-Genetic Determinants of Central Adiposity. International Journal of Obesity;21:839-845

Satoto, Sri Karjati, Boedhi Dharmojo, Tjokroprawiro A, Kodhyat BA. 1998. Kegemukan, Obesitas, dan Penyakit Degeneratif: Epidemiologi dan Strategi Penanggulangan. Prosiding Widya Karya Nasional Pangan Dan Gizi VI 17-20 Februari.

Seidell JC, Perusse L, Despres JP, Bouchard C . 2001. Waist and Hip circumference have Independent and Opposite Effect on Cardiovaskular Disease Risk Factor. Am J Clin Nutr [serial online] [dikutip pada 28 juli 2007];74(3):31521.

Sienkiewicz SF, Whitney E. 2006. Nutrition concepts and controversies. 10th ed. Wadsworth. Thomson; p. 333-312

Soegondo Sidartawan. 2005. Perjalanan Obesitas Menuju Diabetes dan Penyakit Kardiovaskuler. Jakarta : FKUI. RSCM; hal. 1-23

Sudarmani Djoko. 1997. Faktor-faktor Yang Berhubungan Rasio Lingkar Pinggang Lingkar Pinggul Orang Dewasa (kasus Padang). Tesis. Universitas Indonesia. Jakarta. Available from http://www.digilib.ui.edu/ Supariasa, Bachyar Bakri, Ibnu Fajar. 2002. Penilaian Status Gizi. Jakarta: Penerbit Buku Kedokteran EGC. 
Trichopoulou A, Gnardellis C, Lagiou A, Benetou E, Naska A, Trichopoulos D. 2001. Physical activity and energy intake selectively predict the waist-to-bip ratio in men but not in women. Am J Clin Nutr;74:574-8

Troisi R, Heinhold J, Vokonas P, Weiss S. 1991. Cigarette smoking, dietary intake and physical activity: effect on body fat distribution-the Normative Aging Study. Am J Clin Nutr ;53:1104-1111

Uauy R, Albala C, Kain J. 2001. Obesity Trends in Latin America: Transiting from Under to Overweight. USA : American Society For Nutrition Sciences: p 894s.

Whitney EN, Rolfes SR. 2002. Understanding Nutrition. 9th Ed. Belmont, California:Wadsworth Thomson;292-240

Williams MH. 1995. Nutrition for Fitness and Sport. $4^{\text {th }}$ Ed. USA;Brown and Benchmark Publisher.

Wirakusumah, Emma S. 2001. Cara Aman dan Efektif Menurunkan Berat Badan. PT. Gramedia Pustaka Utama: Jakarta

Worobey J. 2006. Behavioral aspects of overweight and obesity. In : Worobey J, Tepper BJ, Kanarek R. Nutrition and behavior. A Multidisciplinary Approach. Cambridge, USA: CABI. p. 253-233 